\section{Does Foliar Zinc Application Boost Leaf Photosynthesis of 'Wichita' Pecan Fertigated with Zinc-EDTA?}

\author{
Cyrus A. Smith, James L. Walworth, and Mary J. Comeau \\ Department of Environmental Science, University of Arizona, 429 Shantz \\ Building \#38, Tucson, AZ 85721
}

Richard J. Heerema
Department of Plant and Environmental Sciences, New Mexico State
University, Las Cruces, NM 88003

Joshua D. Sherman

Arizona Cooperative Extension, University of Arizona, Willcox, AZ 85643

Additional index words. Carya illinoinensis (Wangenh.) K. Koch, nutrients, photosynthesis, spray

Abstract. Many growers fertigating their orchards with zinc-ethylenediaminetetraacetic acid (Zn-EDTA) are still using supplemental zinc foliar sprays because of a lack of confidence that soil-applied Zn-EDTA is supplying enough $Z \mathbf{Z n}$ to the trees. A field study was conducted in a pecan orchard located near San Simon, AZ, on 8-year-old 'Wichita' trees growing in an alkaline, calcareous Vekol loam soil to evaluate the effectiveness of supplemental foliar $\mathrm{Zn}$ sprays. All trees were fertigated with $6.0 \mathrm{~kg} \cdot \mathrm{ha}^{-1}$ $\mathrm{Zn}$ in the form of $\mathrm{Zn}$-EDTA in 2018 and $11.0 \mathrm{~kg} \cdot \mathrm{ha}^{-1} \mathrm{Zn}$ in 2019 and did not exhibit visible signs of $\mathrm{Zn}$ deficiency. Foliar treatments of $3.75 \mathrm{~mL} \cdot \mathrm{L}^{-1}$ urea-ammonium nitrate (UAN), $3.6 \mathrm{~g} \cdot \mathrm{L}^{-1}$ zinc sulfate monohydrate $\left(\mathrm{ZnSO}_{4} \cdot \mathrm{H}_{2} \mathrm{O}\right), 3.6 \mathrm{~g} \cdot \mathrm{L}^{-1} \mathrm{ZnSO}_{4} \cdot \mathrm{H}_{2} \mathrm{O}$ with $3.75 \mathrm{~mL} \cdot \mathrm{L}^{-1} \mathrm{UAN}, 11 \mathrm{~mL} \cdot \mathrm{L}^{-1} \mathrm{Zn}$-EDTA, and water alone were applied to individual fruiting shoot terminals of trees on two dates each in 2018 and 2019. Treatments were sprayed directly onto the leaves of the selected terminals. Zn-EDTA was included as a foliar treatment in 2019 only. Leaf photosynthesis was measured to determine the impact of leaf $\mathrm{Zn}$ concentrations on plant function. Midday stem water potential (MDSWP) was measured to verify that water stress was not limiting photosynthesis. Both measurements were taken about 2 to 4 weeks after the application of foliar treatments. MDSWP measurements indicated a lack of water stress and therefore no effect on photosynthesis. Leaf samples collected from untreated branches indicated that the average foliar $\mathrm{Zn}$ concentration of untreated leaves was $21.3 \mathrm{mg} \cdot \mathrm{kg}^{-1}$ in 2018 and $15.7 \mathrm{mg} \cdot \mathrm{kg}^{-1}$ in 2019 . No differences were observed in photosynthesis rates of treated branches. No additional benefit to leaf photosynthetic function or appearance was observed from spraying $\mathrm{Zn}$ on foliage of trees fertigated with $\mathrm{Zn}$-EDTA.

Pecans [Carya illinoinensis (Wangenh.) K. Koch] require more $\mathrm{Zn}$ than many crops and can tolerate applications of $\mathrm{Zn}$ that would cause toxicity in other plants (Worley, 2002). High-pH calcareous soils are common in the semiarid southwestern United States. In these alkaline soils, Zn binds with hydroxyls and carbonates to form low-solubility compounds, making it less available to plants (Udo et al., 1970). Lack of $\mathrm{Zn}$ availability frequently leads to $\mathrm{Zn}$ deficiency in desert-grown pecans.

Low concentrations of leaf chlorophyll are one result of $\mathrm{Zn}$ deficiency. $\mathrm{Hu}$ and Sparks (1991) found that leaf chlorophyll content was

Received for publication 10 Jan. 2021. Accepted for publication 7 Mar. 2021.

Published online 29 April 2021.

J.L.W. is the corresponding author. E-mail: walworth@ag.arizona.edu.

This is an open access article distributed under the CC BY-NC-ND license (https://creativecommons.org/licenses/by-nc-nd/4.0/). lower in leaves containing less than 14 palisade cells, increase intercellular space, and reduce leaf thickness and surface area (OjedaBarrios et al., 2012). Hu and Sparks (1991) noted that stomatal conductance $\left(g_{\mathrm{S}}\right)$ and net photosynthesis $\left(\mathrm{P}_{\mathrm{n}}\right)$ were reduced concomitantly by low Zn levels. Heerema et al. (2017) determined a threshold leaf $\mathrm{Zn}$ concentration between 14 and $22 \mathrm{mg} \cdot \mathrm{kg}^{-1}$, below which $P_{n}$ declined and above which $\mathrm{P}_{\mathrm{n}}$ did not increase, supporting the findings of $\mathrm{Hu}$ and Sparks (1991). Measurements taken in June and July showed leaf $\mathrm{Zn}$ concentration thresholds on the upper end of this spectrum, whereas measurements acquired in August showed leaf $\mathrm{Zn}$ concentration thresholds on the lower end. $\mathrm{Zn}$ concentrations close to or less than $14 \mathrm{mg} \cdot \mathrm{kg}^{-1}$ prevent normal fruit production on the supporting shoot (Hu and Sparks, 1990).

For field production, the minimum leaf $\mathrm{Zn}$ concentration recommended to avoid loss of yield or nut quality, reduction in vegetative $\mathrm{mg} \cdot \mathrm{kg}^{-1} \mathrm{Zn}$. Zn deficiency can also shorten growth, and visible symptoms of $\mathrm{Zn}$ deficiency is usually reported to be at least 40 to 60 $\mathrm{mg} \cdot \mathrm{kg}^{-1}$ (Heerema, 2013; Robinson et al., 1997; Smith et al., 2012; Sparks, 1993; Sparks and Payne, 1982). Zn-EDTA applied to the soil through fertigation over a 5 -year period at rates of 2.2 and $4.4 \mathrm{~kg} \cdot \mathrm{ha}^{-1} \mathrm{Zn}$ largely eliminated foliar $\mathrm{Zn}$ deficiency symptoms and increased rates of $P_{n}$ (Heerema et al., 2017; Walworth et al., 2017), but these treatments were not sufficient to attain the recommended minimum concentrations. The greatest leaf $\mathrm{Zn}$ concentrations obtained during this study were $35 \mathrm{mg} \cdot \mathrm{kg}^{-1}$, but $P_{n}$ showed no significant increase when foliar $\mathrm{Zn}$ concentrations exceeded $\approx 22 \mathrm{mg} \cdot \mathrm{kg}^{-1}$, indicating that $\mathrm{P}_{\mathrm{n}}$ is not $\mathrm{Zn}$ limited beyond this point.

Foliar application of $\mathrm{Zn}$ is a common practice to alleviate $\mathrm{Zn}$ deficiency. However, managing $\mathrm{Zn}$ with foliar applications is costly and time intensive, and foliar-applied $\mathrm{Zn}$ is poorly distributed within the plant (Wadsworth, 1970). Although foliar application is effective for increasing leaf tissue $\mathrm{Zn}$ concentrations, only a small fraction of applied $\mathrm{Zn}$ is actually absorbed. Wadsworth (1970) indicated that only $0.6 \%$ to $1.2 \%$ of $\mathrm{Zn}$ applied to immature pecan leaves was absorbed. In walnuts Brown et al. (1995) found that $\approx 2 \%$ to $4 \% \mathrm{Zn}$ was absorbed by mature leaves, whereas more than $8 \%$ was absorbed by immature leaves. Foliar $\mathrm{Zn}$ absorption may be dependent on the form of $\mathrm{Zn}$ applied. Frequently used spray materials include $\mathrm{ZnSO}_{4}$ and zinc nitrate $\left[\mathrm{Zn}\left(\mathrm{NO}_{3}\right)_{2}\right]$. In $\mathrm{Zn}$ spray-tank mixes that contain nitrate, the nitrate ion aids in the uptake of $\mathrm{Zn}$ (Worley, 2002). Urea has been reported to enhance the penetration of nutrients into foliar tissues (Hsu and Ashmead, 1984). Storey (1977) observed that foliar absorption of $\mathrm{Zn}$ from either $\mathrm{ZnSO}_{4}$ or $\mathrm{Zn}\left(\mathrm{NO}_{3}\right)_{2}$ sprays was enhanced by including UAN in the spray mixture. In other crops, a mixture of manganese sulfate, $\mathrm{ZnSO}_{4}$, and iron sulfate salts were applied to soybean, fava bean, pea, and wheat with and without the addition of $1 \%$ urea. In all cases, the addition of urea enhanced the uptake of these metals (El-Fouly et al., 1990).

Ferrandon and Chamel (1988) found that the cuticular sorption of $\mathrm{Zn}$ was significantly greater when $\mathrm{Zn}$ was applied to the cuticles of tomato leaves in the inorganic forms of $\mathrm{ZnSO}_{4}$ or zinc chloride than in the organic $\mathrm{Zn}$-EDTA form. $\mathrm{Cu}$ ticular sorption of Zn-EDTA was $\approx 5$ $\mathrm{nM} \cdot \mathrm{cm}^{-2}$ after $72 \mathrm{~h}$ vs. $\approx 41 \mathrm{nM} \cdot \mathrm{cm}^{-2}$ for $\mathrm{ZnSO}_{4}$. In pea plants, $\mathrm{Zn}$ uptake rates were $\approx 1.45$ times greater when $\mathrm{Zn}$ was applied as $\mathrm{ZnSO}_{4}$ vs. Zn-EDTA. More of the $\mathrm{Zn}$ applied in the form of Zn-EDTA was translocated away from the point of foliar contact than that applied as $\mathrm{ZnSO}_{4}$ (Ferrandon and Chamel, 1988). Brown et al. (1995) found that walnut tree leaves sprayed with Zn-EDTA did not contain significantly more $\mathrm{Zn}$ than leaves sprayed with $\mathrm{ZnSO}_{4}$. However, $\mathrm{Zn}$ concentrations of unsprayed leaves on branches adjacent to those sprayed with Zn-EDTA were 
increased significantly compared with the control, whereas leaves on branches adjacent to $\mathrm{ZnSO}_{4}$ treatments were not, suggesting greater mobility of Zn-EDTA within the tree than $\mathrm{ZnSO}_{4}$. In pecans, foliar applications of 50,100 , and 150 $\mathrm{mg} \cdot \mathrm{L}^{-1} \mathrm{Zn}$-EDTA resulted in an increase in leaf $\mathrm{Zn}$ concentrations, chlorophyll content, and leaflet area (Ojeda-Barrios et al., 2014); however, Zn-EDTA sprays generally did not bring foliar $\mathrm{Zn}$ concentrations to the desired level of at least 40 to $60 \mathrm{mg} \cdot \mathrm{kg}^{-1}$. They did, however, achieve the $14-$ to $22-\mathrm{mg} \cdot \mathrm{kg}^{-1}$ concentrations suggested by the data of Heerema et al. (2017).

The identification of adequate minimum pecan foliar $\mathrm{Zn}$ concentrations for commercial field-level recommendations is still open to question. Although the results of Heerema et al. (2017) suggest that 14 to $22 \mathrm{mg} \cdot \mathrm{kg}^{-1}$ is adequate to maximize rates of $\mathrm{P}_{\mathrm{n}}$, recommendations for commercial orchards are generally much greater (at least 40 to $60 \mathrm{mg} \cdot \mathrm{kg}^{-1}$ ) (Heerema, 2013; Robinson et al., 1997; Smith et al., 2012; Sparks, 1993; Sparks and Payne, 1982). In part, these greater mean leaf $\mathrm{Zn}$ concentration recommendations are the result of the treeto-tree variability in leaf $\mathrm{Zn}$ that exists within an orchard (Sparks, 1993; Sparks and Payne, 1982). Finally, it is possible that when $\mathrm{Zn}$ is applied to foliage, as continues to be the common practice, $\mathrm{Zn}$ affects the relationship with $\mathrm{P}_{\mathrm{n}}$ in fundamentally different ways than when it is soil applied. In this study, we explore whether foliar $\mathrm{Zn}$ applications (in the form of $\mathrm{Zn}$ EDTA, $\mathrm{ZnSO}_{4} \cdot \mathrm{H}_{2} \mathrm{O}$ alone or in combination with UAN) will increase leaf $\mathrm{P}_{\mathrm{n}}$ of 'Wichita' pecan trees that are already receiving soil-applied Zn-EDTA.

\section{Materials and Methods}

Study site and fertilization treatments. An experiment was conducted in a commercial pecan orchard near San Simon, AZ (lat. $32^{\circ} 15^{\prime} 20.2^{\prime \prime} \mathrm{N}$, long. $109^{\circ} 10^{\prime} 29.8^{\prime \prime} \mathrm{W}$; elevation, $1118 \mathrm{~m})$. Soil in this orchard block is Vekol loam (fine, mixed, superactive, thermic Typic Haplargids). The 'Wichita' trees in this experiment, grafted to open-pollinated 'Ideal' rootstocks, were planted in the orchard in 2011. The study had a randomized complete block design. Each tree is considered a block and each treated branch is an experimental unit. The orchard's climate is semiarid and has an average annual precipitation of $\approx 24 \mathrm{~cm}$ (Western Regional Climate Center, n.d.). The orchard is irrigated through a microsprinkler system $\approx 24$ times per year $(\approx 152 \mathrm{~cm}$ annually). Nitrogen, phosphorus $(\mathrm{P})$, and potassium $(\mathrm{K})$ were applied through the fertigation system on five occasions, March through June, at rates of 213, 50.5 , and $50.5 \mathrm{~kg} \cdot \mathrm{ha}^{-1}$, respectively, in both 2018 and 2019. Sequestar Zn-EDTA (Brandt Inc., Springfield, IL) containing $9 \% \mathrm{Zn}$ was applied to all trees in the orchard block at a rate of $6.0 \mathrm{~kg} \cdot \mathrm{ha}^{-1} \mathrm{Zn}$ in 2018 and $11.0 \mathrm{~kg} \cdot \mathrm{ha}^{-1} \mathrm{Zn}$ in 2019. Trees did not exhibit observable signs of $\mathrm{Zn}$ deficiency. In both years, $2.24 \mathrm{~kg} \cdot \mathrm{ha}^{-1} \mathrm{~K}$ and $1.12 \mathrm{~kg} \cdot \mathrm{ha}^{-1} \mathrm{Ni}$ were applied to the foliage in June (April/May), and $4.48 \mathrm{~kg} \cdot \mathrm{ha}^{-1} \mathrm{~K}$ and $2.24 \mathrm{~kg} \cdot \mathrm{ha}^{-1} \mathrm{Fe}$ were applied to the foliage in June. Standard commercial weed and insect control measures were conducted by the grower-cooperator. Both varieties in this orchard block exceeded Arizona averages of 1838 and $2129 \mathrm{~kg} \cdot \mathrm{ha}^{-1}$ in 2018 and 2019, respectively (U.S. Department of Agriculture, n.d.). In 2018, yields were $2501 \mathrm{~kg} \cdot \mathrm{ha}^{-1}$ for 'Western' and $2829 \mathrm{~kg} \cdot \mathrm{ha}^{-1}$ for 'Wichita'; in 2019, yields were $3262 \mathrm{~kg} \cdot \mathrm{ha}^{-1}$ for 'Western' and 3292 $\mathrm{kg} \cdot \mathrm{ha}^{-1}$ for 'Wichita'. Percent kernel was $58.5 \%$ for 'Western' in 2018 and $59.4 \%$ for 'Wichita', and $61.3 \%$ for 'Western' and $66.9 \%$ for 'Wichita' in 2019. Average 'Western' nut size was $7.0 \mathrm{~g} /$ nut and 'Wichita' nut size was $7.8 \mathrm{~g} /$ nut in 2018, and $6.6 \mathrm{~g} /$ nut for 'Western' and $7.7 \mathrm{~g} /$ nut for 'Wichita' in 2019.

Experimental foliar treatments. Fruiting shoot terminals with full sun exposure were chosen from each of seven trees selected for this study. One of five different foliar spray treatments were applied to the individually selected shoots on each of the seven trees (replicates). The foliar treatments were 1) water control (distilled water alone), 2) UAN control (3.75 mL. $\left.\mathrm{L}^{-1} \mathrm{UAN}\right), 3$ ) $\mathrm{ZnSO}_{4}$ (3.6 $\left.\mathrm{g} \cdot \mathrm{L}^{-1} \mathrm{ZnSO}_{4} \cdot \mathrm{H}_{2} \mathrm{O}(36 \% \mathrm{Zn}), 4\right) \mathrm{ZnSO}_{4}$ plus UAN $\left(3.6 \mathrm{~g} \cdot \mathrm{L}^{-1} \mathrm{ZnSO}_{4} \cdot \mathrm{H}_{2} \mathrm{O}+3.75 \mathrm{~mL} \cdot \mathrm{L}^{-1}\right.$ UAN), and 5) Zn-EDTA (11 $\mathrm{mL} \cdot \mathrm{L}^{-1} \mathrm{Zn}$ EDTA, applied in 2019 only).

To prevent spray for one treatment from drifting onto other nearby shoot terminals in the study, a plastic bag with a small hole cut in one corner was closed over each shoot terminal while the spray was being applied. Fertilizer formulations were applied by hand with a spray bottle through the hole until all leaves were thoroughly wetted. The bag was then shaken to ensure all leaf surfaces were coated, and then the bag was removed. Applications were done on 24 May and 25 June 2018, and 24 May and 1 July 2019.

Leaf samples and $P_{n}$ measurements. Gas exchange measurements were acquired on middle leaflets from nonterminal, sun-lit leaves on each treated shoot in June and July 2018 and 2019, about 2 to 4 weeks after spray applications. A portable $\mathrm{P}_{\mathrm{n}}$ system (LI-6800; LI-COR, Lincoln, $\mathrm{NE})$ equipped with a red/blue light source (Li-6800-02) was used. Photosynthetically active radiation $(P A R)$ in the chamber was maintained at $1700 \mu \mathrm{mol} \cdot \mathrm{m}^{-2} \cdot \mathrm{s}^{-1}$. Light saturation of $\mathrm{P}_{\mathrm{n}}$ for pecan is reached between a PAR level of 1500 to 1700 $\mu \mathrm{mol} \cdot \mathrm{m}^{-2} \cdot \mathrm{s}^{-1}$ (Anderson, 1994; Lombardini et al., 2009). The reference carbon dioxide $\left(\mathrm{CO}_{2}\right)$ concentration was kept at 400 $\mu \mathrm{mol} \cdot \mathrm{mol}^{-1}$, near the global mean atmospheric concentration (U.S. Department of Commerce, 2020). After $\mathrm{P}_{\mathrm{n}}$ and $g_{\mathrm{S}}$ stabilized (typically between $30-60 \mathrm{~s}$ after the chamber was clamped onto the leaf), gas exchange data were logged for each leaf. Gas exchange measurements were taken between 0900 and $1300 \mathrm{HR}$.

Following the technique described by Fulton et al. (2014), MDSWP was measured for each tree on the same dates as the gas exchange measurements were acquired. Sealed reflective bags were placed over a shaded leaf in the lower interior part of the tree and equilibrated for $\approx 30 \mathrm{~min}$. The leaf was then cut from the tree and the water potential was measured immediately using a Scholander pressure chamber (PMS Instrument Co., Albany, OR).

About 30 leaflets were collected from untreated fruiting shoots on the opposite side of each tree from the treated branches on 25 June 2018 and 7 June 2019 to determine background $\mathrm{Zn}$ concentrations. On 18 June 2018, 20 leaflets were also collected from the treated shoots. All leaflets were washed in a P-free detergent, and then rinsed in deionized water, followed by a $1 \%$ hydrochloric acid bath and a final rinse in deionized water. The leaflets were spun dry and placed in an oven for 48 $\mathrm{h}$ at $65^{\circ} \mathrm{C}$. They were then ground using a cyclone mill (UDY Cyclone Sample Mill, Belt Drive, model 3010-030, 120 Volt ac; UDY Corporation, Fort Collins, CO).

A 0.5 -g aliquot of ground leaf tissue was ashed at $500^{\circ} \mathrm{C}$ for $5.5 \mathrm{~h}$, dissolved in $10 \mathrm{~mL}$ $2.0 \mathrm{~N}$ hydrochloride, and diluted to $50 \mathrm{~mL}$. Concentrations of $\mathrm{Zn}$ were analyzed with an atomic absorption spectrometer (model 3100; PerkinElmer, Waltham, MA) at a wavelength of $213.9 \mathrm{~nm}$.

JMP Pro 15 software (SAS Institute, Cary, NC) was used to perform analysis of variance. Connecting letters reports to show differences in the means for all data in figure and table form were obtained using each pair Student's $t$ tests. JMP software was also used to perform linear regressions to determine the relationship between MDSWP and $\mathrm{P}_{\mathrm{n}}$. An alpha value of 0.05 was used in all statistical tests.

\section{Results and Discussion}

Average background leaf $\mathrm{Zn}$ concentrations of untreated leaves (i.e., those collected from the opposite side of the tree from

Table 1. Leaf zinc $(\mathrm{Zn})$ concentrations averaged from all individually sampled pecan trees for each of four treatments taken July $18,2018,23 \mathrm{~d}$ after treatment application, and leaf $\mathrm{Zn}$ concentrations averaged from untreated samples taken from the backside of each tree on 25 June 2018 . Values that do not share the same letter are statistically different.

\begin{tabular}{|c|c|c|c|c|c|}
\hline Leaf samples & Untreated & Water & Water + UAN & $\mathrm{ZnSO}_{4} \cdot \mathrm{H}_{2} \mathrm{O}$ & $\mathrm{ZnSO}_{4} \cdot \mathrm{H}_{2} \mathrm{O}+\mathrm{UAN}$ \\
\hline Average $\mathrm{Zn}$ concentration $\left(\mathrm{mg} \cdot \mathrm{kg}^{-1}\right)$ & $21.3 \mathrm{c}$ & $21.1 \mathrm{c}$ & $22.5 \mathrm{c}$ & $126.8 \mathrm{~b}$ & $151.5 \mathrm{a}$ \\
\hline
\end{tabular}


the sprayed branches) in our study were $21.3 \mathrm{mg} \cdot \mathrm{kg}^{-1}$ in 2018 and $15.7 \mathrm{mg} \cdot \mathrm{kg}^{-1}$ in 2019. In 2018, leaf tissue $\mathrm{Zn}$ concentrations from shoots treated with water alone (21.1 $\left.\mathrm{mg} \cdot \mathrm{kg}^{-1}\right)$ or water $+\mathrm{UAN}\left(22.5 \mathrm{mg} \cdot \mathrm{kg}^{-1}\right)$ were not statistically different from that of untreated leaves sampled from the opposite side of the canopy $\left(21.3 \mathrm{mg} \cdot \mathrm{kg}^{-1}\right.$ ) (Table 1). The leaf $\mathrm{Zn}$ concentrations from shoots treated with $\mathrm{Zn}$-containing sprays were significantly greater than those of shoots treated with water alone or water + UAN. The addition of UAN to $\mathrm{ZnSO}_{4} \cdot \mathrm{H}_{2} \mathrm{O}$ treatments increased leaf $\mathrm{Zn}$ concentrations significantly relative to $\mathrm{ZnSO}_{4} \cdot \mathrm{H}_{2} \mathrm{O}$ alone, confirming the findings of Storey (1977). Comparable measurements were not made in 2019.

$\mathrm{P}_{\mathrm{n}}$ measured on two dates each in 2018 and 2019 is shown in Fig. 1. No significant differences were noted. There was no significant difference in $g_{\mathrm{S}}$ on any of the measurement dates (data not shown). The overall average $g_{\mathrm{S}}$ from all four measurement dates was $0.210 \mathrm{~mol} \cdot \mathrm{m}^{-2} \cdot \mathrm{s}^{-1}$. Only one significant difference was found in levels of intercellular $\mathrm{CO}_{2}$; the water + UAN treatment had significantly lower levels than the other treatments on 18 July 2018 (Table 2).

The observation that application of additional $\mathrm{Zn}$, either with or without UAN, did not increase rates of $P_{n}$ on any of the measurement dates suggests that $P_{n}$ rates were not limited by lack of $\mathrm{Zn}$ on trees where $\mathrm{Zn}$ fertilizers were applied exclusively to the soil. Maximum $P_{n}$ rates in southwestern 'Wichita' pecans has been reported to be between 16 and $18 \mu \mathrm{mol} \cdot \mathrm{m}^{-2} \cdot \mathrm{s}^{-1}$ (Heerema et al., 2017), whereas rates in our study ranged from 12.2 to $17.1 \mu \mathrm{mol} \cdot \mathrm{m}^{-2} \cdot \mathrm{s}^{-1}$, slightly less than typical maximum rates. Both Heerema et al., (2017) and $\mathrm{Hu}$ and Sparks (1991) found that maximum $P_{n}$ was observed in pecans when leaf $\mathrm{Zn}$ concentrations were at least 14 to $22 \mathrm{mg} \cdot \mathrm{kg}^{-1}$. The level of $\mathrm{Zn}$ in untreated branches in 2018 was $21.3 \mathrm{mg} \cdot \mathrm{kg}^{-1}$, high enough that additional $\mathrm{Zn}$ was not expected to elicit a response based on the findings of Heerema et al. (2017) and Hu and Sparks (1991), but well below other published standards of at least 40 to $60 \mathrm{mg} \cdot \mathrm{kg}^{-1}$. In 2019 , the average leaf $\mathrm{Zn}$ concentration was $15.7 \mathrm{mg} \cdot \mathrm{kg}^{-1}$, within a range in which $P_{n}$ could potentially be limited by inadequate foliar $\mathrm{Zn}$. Our data indicate that rates of $P_{n}$ were not limited by the concentrations of foliar $\mathrm{Zn}$ and that no benefit with respect to $P_{n}$ was observed from foliar $\mathrm{Zn}$ sprays. However, further research is needed to determine whether these foliar $\mathrm{Zn}$ concentrations have an impact on other horticulturally relevant vegetative and reproductive tree functions that were not measured in this study.

Many different kinds of environmental stresses can limit rates of $P_{n}$ in pecans, including those related to insufficient nutrients, sunlight, and water (e.g., Heerema et al., 2014; Lombardini et al., 2009; Othman et al., 2014). Othman et al. (2014) found that water potentials less than $-0.9 \mathrm{MPa}$ reduced pecan
Foliar Treaments and Photosynthesis Rates in 2018 and 2019

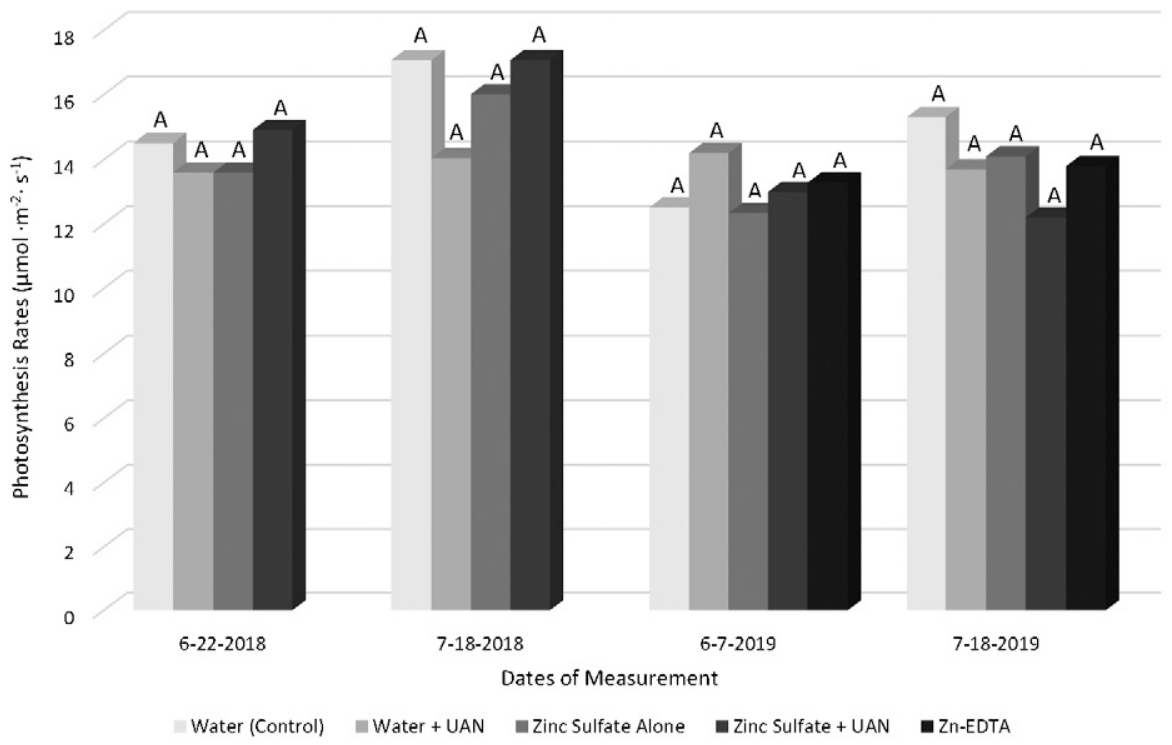

Fig 1. Photosynthesis rates of sprayed shoots in 2018 and 2019. The mean photosynthesis rate for treatments from all seven pecan trees (replicates) on each of four measurement dates are compared. Treatments that do not share the same letter within the same sampling date are significantly different. EDTA, ethylenediaminetetraacetic acid; UAN, urea-ammonium nitrate; Zn, zinc.

Table 2. Intercellular carbon dioxide concentrations (measured in micromoles per mole) on all four measurement dates.

\begin{tabular}{lcccc}
\hline Treatment & 22 July 2018 & 18 July 2018 & 7 June 2019 & 18 July 2019 \\
\hline Water & $236.71 \mathrm{a}$ & $264.48 \mathrm{a}$ & $237.18 \mathrm{a}$ & $264.72 \mathrm{a}$ \\
Water + urea-ammonium nitrate & $224.86 \mathrm{a}$ & $245.66 \mathrm{~b}$ & $244.24 \mathrm{a}$ & $265.15 \mathrm{a}$ \\
Zinc sulfate & $231.43 \mathrm{a}$ & $267.59 \mathrm{a}$ & $241.92 \mathrm{a}$ & $264.30 \mathrm{a}$ \\
Zinc + urea-ammonium nitrate & $233.14 \mathrm{a}$ & $263.30 \mathrm{ab}$ & $239.93 \mathrm{a}$ & $261.09 \mathrm{a}$ \\
Zinc-ethylenediaminetetraacetic acid & - & - & $246.45 \mathrm{a}$ & $261.27 \mathrm{a}$ \\
\hline
\end{tabular}

Values in each column that do not share the same letter are statistically different.

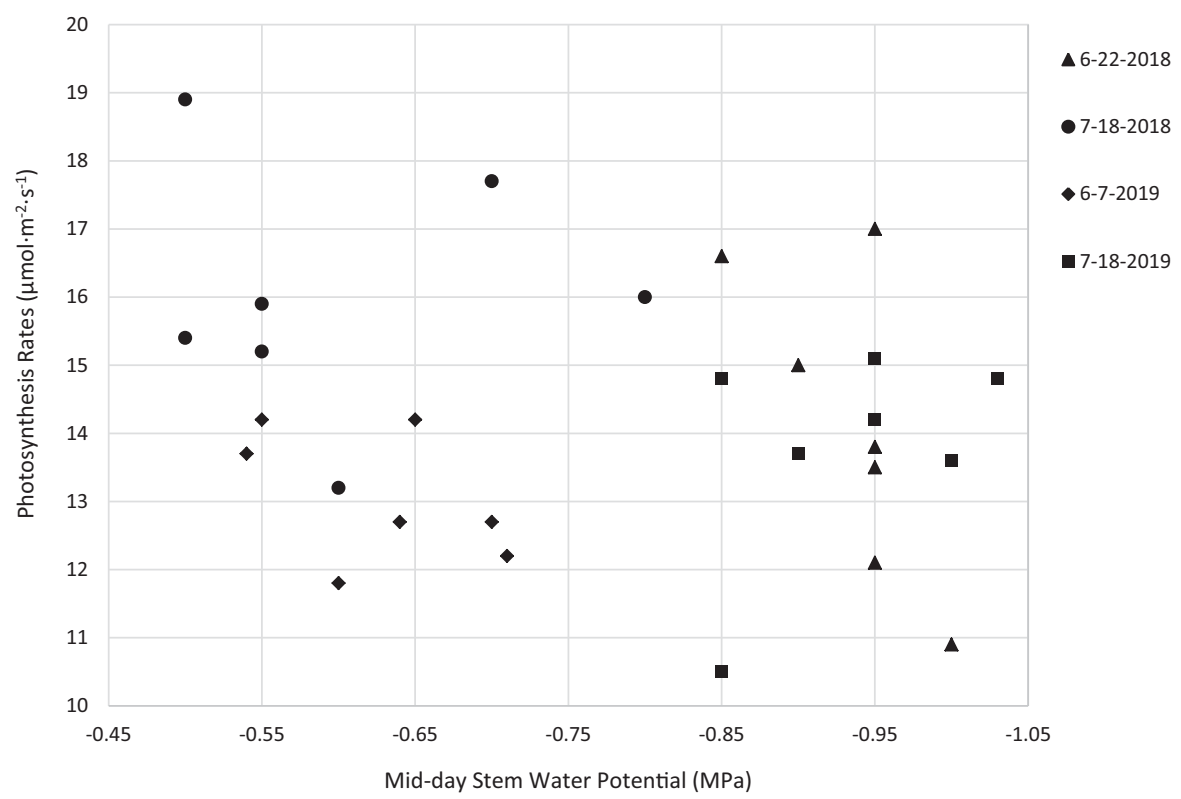

Fig. 2. Relationship between midday stem water potential (MDSWP) and photosynthesis rates for all seven pecan trees (replicates) in the experiment. $P$ values of 0.076 on 22 June 2018, 0.979 on 18 July $2018,0.280$ on 7 June 2019 , and 0.292 on 18 July 2019 were obtained. With an alpha value of 0.05 , none of these relationships were significant. 
$P_{n}$. Our values were close to or greater than this level on all measurement dates. $P_{n}$ averaged across all treatments for each tree was plotted vs. MDSWP and linear regressions performed on data from each measurement date to evaluate the effect of MDSWP on $\mathrm{P}_{n}$ (Fig. 2). Statistical analysis showed no indication that $\mathrm{P}_{\mathrm{n}}$ corresponded to MDSWP. Although combining the data indicates a nonsignificant weak trend $\left(r^{2}=0.0415\right)$ toward declining $\mathrm{P}_{\mathrm{n}}$ with increasing water stress, we conclude that water stress was probably not an important factor in our study.

\section{Conclusion}

The measured rates of $P_{n}$ suggest that leaf tissue $\mathrm{Zn}$ concentrations did not limit $\mathrm{P}_{\mathrm{n}}$ in our study. MDSWP measurements indicate that water stress did not limit $P_{n}$. We conclude that supplemental foliar $\mathrm{Zn}$ sprays did not confer any additional benefit to leaf photosynthesis of pecan trees in Zn-EDTA-fertigated orchards with foliar $\mathrm{Zn}$ concentrations in the 16 to $21-\mathrm{mg} \cdot \mathrm{kg}^{-1}$ range, because $P_{n}$ was not $\mathrm{Zn}$ limited under these conditions. However, sprays applied earlier in the growing season may provide some benefit not exhibited by the trees in our study. Our research further questions the validity of greater minimum acceptable foliar $\mathrm{Zn}$ concentrations for Zn-EDTA-fertigated trees. It is recognized that foliar $\mathrm{Zn}$ concentrations vary from tree to tree in an orchard block and that a greater average $\mathrm{Zn}$ concentration is likely needed to ensure that most, or all, trees exceed this range. In addition, further testing is needed to determine whether there are any other horticulturally important benefits from $\mathrm{Zn}$ sprays in these orchards.

\section{Literature Cited}

Anderson, P.C. 1994. Temperate nut species, p. 299-338. In: B. Schaffer and P.C. Anderson (eds.). Handbook of environmental physiology of fruit crops. Vol I: Temperate crops. CRC Press, New York, NY.

Brown, P.H., Q. Zhang, and J. Grant. 1995. Improving walnut zinc nutritional status by foliar sprays. Walnut Research Report. Walnut Marketing Board, Modesto, CA.

El-Fouly, M.M., A.F.A. Fawzi, Z.M. Mobarak, E.A. Aly, and F.E. Abdalla. 1990. Micronutrient foliar intake by different crop plants, as affected by accompanying urea, p. 267-273. In: M.L. Van Beusichem (ed.). Plant nutrition: Physiology and applications: Developments in Plant and Soil Sciences. Vol. 41. Springer, Dordrecht, Netherlands.

Ferrandon, M. and A.R. Chamel. 1988. Cuticular retention, foliar absorption and translocation of $\mathrm{Fe}, \mathrm{Mn}$ and $\mathrm{Zn}$ supplied in organic and inorganic form. J. Plant Nutr. 11(3):247-263, doi: 10.1080/01904168809363800.

Fulton, A., J. Grant, R. Buchner, and J. Connell. 2014. Using the pressure chamber for irrigation management in walnut, almond, and prune. ANR publication 8503. University of California Division of Agriculture and Natural Resources, Davis, CA.

Heerema, R.J. 2013. Diagnosing nutrient disorders of New Mexico pecan trees. Guide H-658. College of Agricultural, Consumer and Environmental Sciences, New Mexico State University, Las Cruces, NM.

Heerema, R.J., D. Van Leeuwen, R. St. Hilaire, V.P. Gutschick, and B. Cook. 2014. Leaf photosynthesis in nitrogen-starved 'Western' pecan is lower on fruiting shoots than non-fruiting shoots during kernel fill. J. Amer. Soc. Hort. Sci. 139:267-274.

Heerema, R.J., D. Van Leeuwen, M.W. Thompson, J.D. Sherman, M.J. Comeau, and J.L. Walworth. 2017. Soil application of zincEDTA increases leaf photosynthesis of immature 'Wichita' pecan trees. J. Amer. Soc. Hort. Sci. 142:27-35.

Hsu, H.H. and H.D. Ashmead. 1984. Effect of urea and ammonium nitrate on the uptake of iron through leaves. J. Plant Nutr. 7(1-5):291-299, doi: 10.1080/01904168409363196.

$\mathrm{Hu}, \mathrm{H}$. and D. Sparks. 1990. Zinc-deficiency inhibits reproductive development in 'Stuart' pecan. HortScience 25:1392-1396.

Hu, H. and D. Sparks. 1991. Zinc deficiency inhibits chlorophyll synthesis and gas exchange in 'Stuart' pecan. HortScience 26:267-268.

Lombardini, L., H. Restrepo-Diaz, and A. Volder. 2009. Photosynthetic light response and epidermal characteristics of sun and shade pecan leaves. J. Amer. Soc. Hort. Sci. 134:372-378.

Ojeda-Barrios, D.L., J. Abadia, L. Lombardini, A. Abadia, and S. Vasquez. 2012. Zinc deficiency in field grown pecan trees: Changes in leaf nutrient concentrations and structure. J. Sci. Food Agr. 92:1672-1678, doi: 10.1002/ jsfa.5530.

Ojeda-Barrios, D.L., E. Perea-Portillo, O.A. Hernandez-Rodriquez, G. Avila-Quezada, J. Abadia, and L. Lombardini. 2014. Foliar fertilization with zinc in pecan trees. HortScience 49:562566.

Othman, Y., D. VanLeeuwen, R. Heerema, and R. St. Hilaire. 2014. Mid-day stem water potential values needed to maintain photosynthesis and leaf gas exchange established for pecan. J. Amer. Soc. Hort. Sci. 139:537-546.

Robinson, J.B., M. Treeby, and R.A. Stephenson. 1997. Fruits, vines and nuts, p. 347-382. In: D.J. Reuter and J.B. Robinson (eds.). Plant analysis: An interpretation manual. CSIRO Publishing, Collingwood, Victoria, Australia.

Smith, M.W., C.T. Rohla, and W.D. Goff. 2012. Pecan leaf elemental sufficiency ranges and fertilizer recommendations. HortTechnology 22: 594-599.

Sparks, D. 1993. Threshold leaf levels of zinc that influences nut yield and vegetative growth in pecan. HortScience 28:1100-1102.

Sparks, D. and J.A. Payne. 1982. Zinc levels in pecan leaflets associated with zinc deficiency. Pecan South 9(5):3234.

Storey, J.B. 1977. Zinc-containing foliar spray. U.S. Patent 4025330. 63-66.

Udo, E.J., H.L. Bohn, and T.C. Tucker. 1970. Zinc adsorption by calcareous soils. Soil Sci. Soc. Amer. Proc. 34(3):405-407.

U.S. Department of Agriculture. (n.d.). National Agricultural Statistical Services. Quick Stats. 13 Feb. 2021. <https://quickstats.nass.usda.gov/>.

U.S. Department of Commerce. 2020. Earth system research laboratory NOAA trends in atmospheric $\mathrm{CO}_{2} .12$ Dec. 2020. <http://www.esrl. noaa.gov/gmd/ccgg/trends/global.html $>$.

Wadsworth, G.L. 1970. Absorption and translocation of zinc in pecan trees (Carya Illinoensis (Wang.) K. Koch)). Texas A\&M University, College Station, TX. MS Thesis.

Walworth, J.L., S.A. White, M.J. Comeau, and R.J. Heerema. 2017. Soil-applied ZnEDTA: Vegetative growth, nut production, and nutrient acquisition of immature pecan trees grown in an alkaline, calcareous soil. HortScience 52:1-5.

Western Regional Climate Center. (n.d). 2 July 2020. <https://wrcc.dri.edu/cgi-bin/ cliMAIN.pl?az7560>.

Worley, R.E. 2002. Compendium of pecan production and research. Edward Brothers Inc., Ann Arbor, MI. 